\title{
Phytohormones on the germination and initial growth of pumpkin seedlings under different types of water
}

\author{
Keylan S. Guirra ${ }^{1}$, Salvador B. Torres ${ }^{1}$, Moadir de S. Leite ${ }^{1}$, Bruno S. Guirra ${ }^{2}$, \\ Francisco A. Nogueira Neto ${ }^{1} \&$ Anna L. B. Rêgo ${ }^{1}$
}

${ }^{1}$ Universidade Federal Rural do Semi-Árido/Departamento de Ciências Agronômicas e Florestais/Programa de Pós-Graduação em Fitotecnia. Mossoró, RN, Brasil.E-mail: ks_guirra@live.com (Corresponding author) - ORCID: 0000-0002-2510-6587; sbtorres@ufersa.edu.br - ORCID: 0000-0003-0668-3327; moadir@outlook.com - ORCID: 0000-0003-0432-0522; assis-neeto@hotmail.com - ORCID: 0000-0001-7037-6941; annaleticia.barbosa02@gmail.com ORCID: 0000-0002-6751-0764

${ }^{2}$ Universidade Federal do Rio Grande do Norte/Unidade Acadêmica Especializada em Ciências Agrárias. Macaíba, RN, Brasil. E-mail: bguirra@hotmail.com - ORCID: 0000-0001-7136-132X

\begin{abstract}
Pumpkin (Curcubita moschata Duchesne) production in quantity and quality is often restricted due to adverse environmental conditions. Thus, the objective was to evaluate the action of phytohormones as stress attenuators on the germination and initial growth of pumpkin seedlings, cv. Sergipana, under different types of water. The design adopted was completely randomized, in a $3 \times 4$ factorial scheme, with four repetitions. In addition to the control, the seeds were treated with the gibberellic and salicylic acids and irrigated with the supply water, fish farming wastewater, artesian well water and solution of the mixture of fish farming wastewater + artesian well water, in a 1:1 ratio. The variables evaluated were germination, first germination count, germination speed index, length of shoots and roots, dry mass of shoots and roots, soluble sugars, amino acids and proline. Treatment of pumpkin seeds, cv. Sergipana, with gibberellic and salicylic acids improved germination kinetics and attenuated the effects of water salinity during the initial growth of pumpkin seedlings.
\end{abstract}

Key words: Cucurbitaceae, Cucurbita spp., gibberellic acid, salicylic acid

\section{Fitohormônios na germinação e crescimento inicial de plântulas de abóbora em diferentes tipos de água}

RESUMO: A produção de abóbora (Curcubita moschata Duchesne) em quantidade e qualidade é muitas vezes restrita em decorrência das condições ambientais adversas. Sendo assim, objetivou-se avaliar a ação de fitohormônios como atenuantes de estresse na germinação e crescimento inicial de plântulas de abóbora, cv. Sergipana, em diferentes tipos de água. O delineamento adotado foi o inteiramente casualizado, em esquema fatorial $3 \times 4$, em quatro repetições. Além do controle, as sementes foram tratadas com os ácidos giberélico e salicílico e irrigadas com as águas de abastecimento, efluente de piscicultura, poço artesiano e solução da mistura de efluente de piscicultura + a de poço artesiano, na proporção de 1:1. As variáveis avaliadas foram germinação, primeira contagem de germinação, índice de velocidade de germinação, comprimento das partes aérea e raiz, massa seca das partes aérea e raiz, açúcares solúveis, aminoácidos e prolina. O tratamento de sementes de abóbora, cv. Sergipana, com os ácidos giberélico e salicílico melhorou a cinética de germinação e atenuaram os efeitos da salinidade da água durante o crescimento inicial de plântulas de abóbora.

Palavras-chave: Cucurbitaceae, Cucurbita spp., ácido giberélico, ácido salicílico 


\section{INTRODUCTION}

Pumpkin (Curcubita moschata Duchesne) is native of the Americas and has worldwide socioeconomic importance, mainly due to its nutritional composition rich, in essential antioxidants and precursors of vitamin A (Resende et al., 2013).

Much of the production of C. moschata occurs in the semi-arid region of northeastern Brazil in rainfed system (Devi et al., 2018). Usually, this region is affected by low water availability, which can cause metabolic disorders in plants (Ó et al., 2020). Thus, the use of wastewater or saline water, from artesian wells, arises as an alternative for agricultural crops. Thus, fish farming wastewater responds well to this trend because they are rich in organic materials and ions important to plant nutrition (Castro et al., 2006). However, the high levels of salts present in these waters can lead to phytotoxicity problems, especially in the early stages of plant development (Silva et al., 2014b). For pumpkins, these stages are highly hampered when saline water is used for irrigation (Oliveira et al., 2014).

To minimize the negative effects of abiotic stresses during germination and initial growth of seedlings, seeds have been treated with phytohormones. Among the most used are those with gibberellic acid (Kandil et al., 2014) and salicylic acid (Silva et al., 2019).

Thus, the objective was to evaluate the effect of phytohormones as attenuators of abiotic stresses during germination and initial growth of C. moschata seedlings under different types of water.

\section{Material ANd Methods}

Fish farming wastewater from tilapia (Oreochomis spp.) production tanks, artesian well water and supply water were obtained on the campus of the Universidade Federal Rural do Semi-Árido (UFERSA), Mossoró, RN, Brazil, and their chemical characteristics are presented in Table 1.

The study was conducted in a completely randomized design, in a $3 \times 4$ factorial scheme, with four repetitions of 50 seeds of C. moschata, cv. Sergipana. The factors corresponded to three seed treatments (control, gibberellic acid and salicylic acid) and four types of water $\left(\mathrm{W}_{1}=\right.$ supply water; $\mathrm{W}_{2}=$ fish farming wastewater; $\mathrm{W}_{3}=$ artesian well water and $\mathrm{W}_{4}=$ mixture of fish farming wastewater + artesian well water, in 1:1 ratio).

The seeds were treated with gibberellic acid (GA) and salicylic acid (SA) at $50 \mathrm{mg} \mathrm{L}^{-1}$ (Silva et al., 2014b) and 30 $\mathrm{mg} \mathrm{L}^{-1}$ (Rafique et al., 2011), respectively. The commercial product ProGibb $400^{\circ}$ was used as source of gibberellic acid.
The seeds were put to soak between three sheets of paper towel $\left(\right.$ Germitest $\left.^{\circledR}\right)$, previously moistened with the acid solutions in the proportion of twice the weight of the dry paper and placed in plastic bags. These bags were later arranged in a germination chamber at $25^{\circ} \mathrm{C}$ and kept for $24 \mathrm{~h}$.

After soaking with phytohormones, the seeds were distributed in four repetitions of 50 seeds on Germitest paper, initially moistened with the different types of water, in an amount equivalent to twice the weight of the dry paper.

The following evaluations were performed: a) germination and first count - after sowing, the paper rolls with the seeds were packed in plastic bags, vertically arranged in germination chamber (Mangelsdorf), at $25^{\circ} \mathrm{C}$ with a $12 \mathrm{~h}$ photoperiod, determining the number of normal seedlings at four and eight days after sowing, and the values were expressed as a percentage (Brasil, 2009); b) germination speed index - daily counts of the number of normal seedlings were performed for eight days, and the index was calculated according to Maguire (1962); c) length of shoots and roots - at the end of the germination test, ten normal seedlings were randomly collected in each replicate and the length was determined using a ruler graduated in $\mathrm{mm}$, with the results expressed in $\mathrm{cm}$; d) dry mass of shoots and roots - after being measured, the seedlings were sectioned into shoots and roots, packed in kraft paper bags, dried in a forced air circulation oven at $65^{\circ} \mathrm{C}$ for $72 \mathrm{~h}$, and then weighed on an analytical precision scale $(0.0001)$, with results expressed in $\mathrm{mg}$.

Biochemical determinations were performed in five normal seedlings, forming a composite sample. Triplicates were then collected to determine the analyses. The quantity of $0.2 \mathrm{~g}$ of fresh mass of seedlings was weighed, placed in hermetically sealed tubes and mixed with $3 \mathrm{~mL}$ of $60 \%$ alcohol. The material was macerated, and the tubes were put in a water bath at $60^{\circ} \mathrm{C}$ for $20 \mathrm{~min}$. Then, they were then centrifuged at $10,000 \mathrm{rpm}$ for $8 \mathrm{~min}$ at $4{ }^{\circ} \mathrm{C}$ and the supernatant was collected to quantify the following components: a) soluble sugars - determined by the Anthrone method (Yemm \& Willis, 1954), using glucose as the standard substance of the curve, with results expressed in $\mathrm{mg}$ of TSS $\mathrm{g}^{-1}$ fresh mass; b) amino acids - determined by the acid ninhydrin method (Yemm \& Cocking, 1955), with glycine as the standard substance of the curve, and the results were expressed in $\mu \mathrm{mol}$ TAA $\mathrm{g}^{-1}$ of fresh mass; c) proline determined by the method proposed by Bates et al. (1973) and the results were expressed in $\mu \mathrm{mol}$ proline $\mathrm{g}^{-1}$ of fresh mass.

The data obtained were subjected to analysis of variance by F test ( $\mathrm{p} \leq 0.05)$ and, in case of significance, subjected to the Scott-Knott test $(\mathrm{p} \leq 0.05)$. The statistical program used was SISVAR $^{\circledast}$ (Ferreira, 2011).

Table 1. Concentration of cations and anions, acidity and electrical conductivity of waters used for the water supply of pumpkin seeds

\begin{tabular}{|c|c|c|c|c|c|c|c|c|c|c|c|}
\hline \multirow{2}{*}{ Waters } & \multirow{2}{*}{$\mathrm{pH}$} & \multirow{2}{*}{$E C-25^{\circ} \mathrm{C}$} & \multicolumn{4}{|c|}{ Cations (mmolc $L^{-1}$ ) } & \multicolumn{3}{|c|}{ Anions $\left(\mathrm{mmol}_{\mathrm{c}} \mathrm{L}^{-1}\right)$} & \multirow{2}{*}{ *SAR } & \multirow{2}{*}{${ }^{* *}$ Class } \\
\hline & & & $\mathrm{Ca}^{2+}$ & $\overline{\mathrm{Mg}^{2+}}$ & $\mathrm{Na}^{+}$ & $\overline{\mathrm{K}^{+}}$ & $\mathrm{CO}_{3}{ }^{2-}$ & $\mathrm{HCO}_{3}$ & $\mathrm{Cl}^{-}$ & & \\
\hline$W_{1}$ & 8.4 & 0.55 & 0.9 & 0.4 & 3.36 & 0.24 & 0.6 & 3.00 & 2.8 & 4.2 & C2S1 \\
\hline$W_{2}$ & 7.9 & 5.97 & 15.7 & 20.1 & 30.99 & 1.13 & 0.6 & 3.40 & 42.0 & 7.3 & C4S1 \\
\hline$W_{3}$ & 8.1 & 5.30 & 18.5 & 20.6 & 21.95 & 0.77 & 6.4 & 5.20 & 6.4 & 5.0 & C4S1 \\
\hline$W_{4}$ & 8.0 & 5.59 & 17.0 & 19.8 & 36.59 & 0.98 & 1.2 & 4.10 & 34.0 & 8.5 & C4S1 \\
\hline
\end{tabular}

$\mathrm{W}_{1}$ - Supply water; $\mathrm{W}_{2}$ - Fish farming wastewater; $\mathrm{W}_{3}$ - Artesian well water; $\mathrm{W}_{4}$ - Mixture of fish farming wastewater + artesian well water, in 1:1 ratio $\left(\mathrm{W}_{2+} \mathrm{W}_{3}\right)$; ${ }^{*}$ Sodium adsorption ratio; ${ }^{* *}$ - Classification of water for irrigation (Richards, 1954) 


\section{Results AND Discussion}

The phytohormones and different types of water applied to the seeds had significant interaction for all variables analyzed. Seeds treated with gibberellic and salicylic acids had higher germination percentages when irrigated with fish farming wastewater $\left(\mathrm{W}_{2}\right)$, artesian well water $\left(\mathrm{W}_{3}\right)$ and mixture of fish farming wastewater + artesian well water $\left(\mathrm{W}_{4}\right)$. For the result obtained with artesian well water + fish farming wastewater $\left(\mathrm{W}_{4}\right)$, it was found that gibberellin promoted higher germination, being $47 \%$ higher than that of the control treatment. However, using the supply water $\left(\mathrm{W}_{1}\right)$ the highest germination percentage was observed in the control treatment (Figure 1A).

Generally, when seeds are subjected to abiotic stresses, lower germination rates are expected (Marcos-Filho, 2015). However, in the absence of good quality water for agricultural use, the use of gibberellic and salicylic acids in seed treatment, when seeds are subjected to fish farming wastewater and well water, are management alternatives. This agricultural practice makes it possible to obtain higher percentages of germination under saline condition, acting in the promotion of cell elongation and division. In addition, exogenous application increases the levels of these regulators; consequently, they act on the aleurone layer, promoting seed germination (Taiz et al., 2017). This fact was verified in Citrullus lanatus L., whose germination was induced with the use of gibberellic acid (Silva et al., 2014b), and salicylic acid under saline conditions (Rafique et al., 2011). This is also similar to the result found in corn seeds pretreated with gibberellic acid (Tsegay \& Andargie, 2018).

The result of the first count test was superior for the control treatment when compared to those of the gibberellic and salicylic acids, with $98 \%$ of normal seedlings under supply water $\left(\mathrm{W}_{1}\right)$ (Figure 1B). However, seeds without treatments had zero normal seedlings under well water + fish farming wastewater $\left(\mathrm{W}_{4}\right)$. However, when treated with regulators, they promoted greater tolerance, as well as germination greater than $60 \%$. It is also observed that treated seeds had superior performance than the control for treatments with fish farming wastewater $\left(\mathrm{W}_{2}\right)$, artesian well water $\left(\mathrm{W}_{3}\right)$ and mixture of fish farming wastewater + artesian well water $\left(\mathrm{W}_{4}\right)$, with no difference between salicylic and gibberellic acids for the number of normal seedlings at four days. This is because plant regulators perform functions of cell elongation and division, even when the seedling is under osmotic stress, stimulating growth and rapid establishment (Taiz et al., 2017).

Seeds treated with plant regulators obtained a higher germination speed index compared to the control under all types of water. However, there was no statistical difference between the regulators within the treatment with more saline waters $\left(\mathrm{W}_{2}, \mathrm{~W}_{3}\right.$ and $\left.\mathrm{W}_{4}\right)$, indicating that the regulators attenuated salt stress and avoided the late establishment of seedlings (Figure 1C). When considering only the supply water, seeds treated with GA germinated $45 \%$ faster than those without treatment. When the speed index was evaluated under the use of well water, fish farming wastewater and mixture of these waters, it was observed that the salicylic and gibberellic acids were similar and led to a $40 \%$ higher level compared to the control.
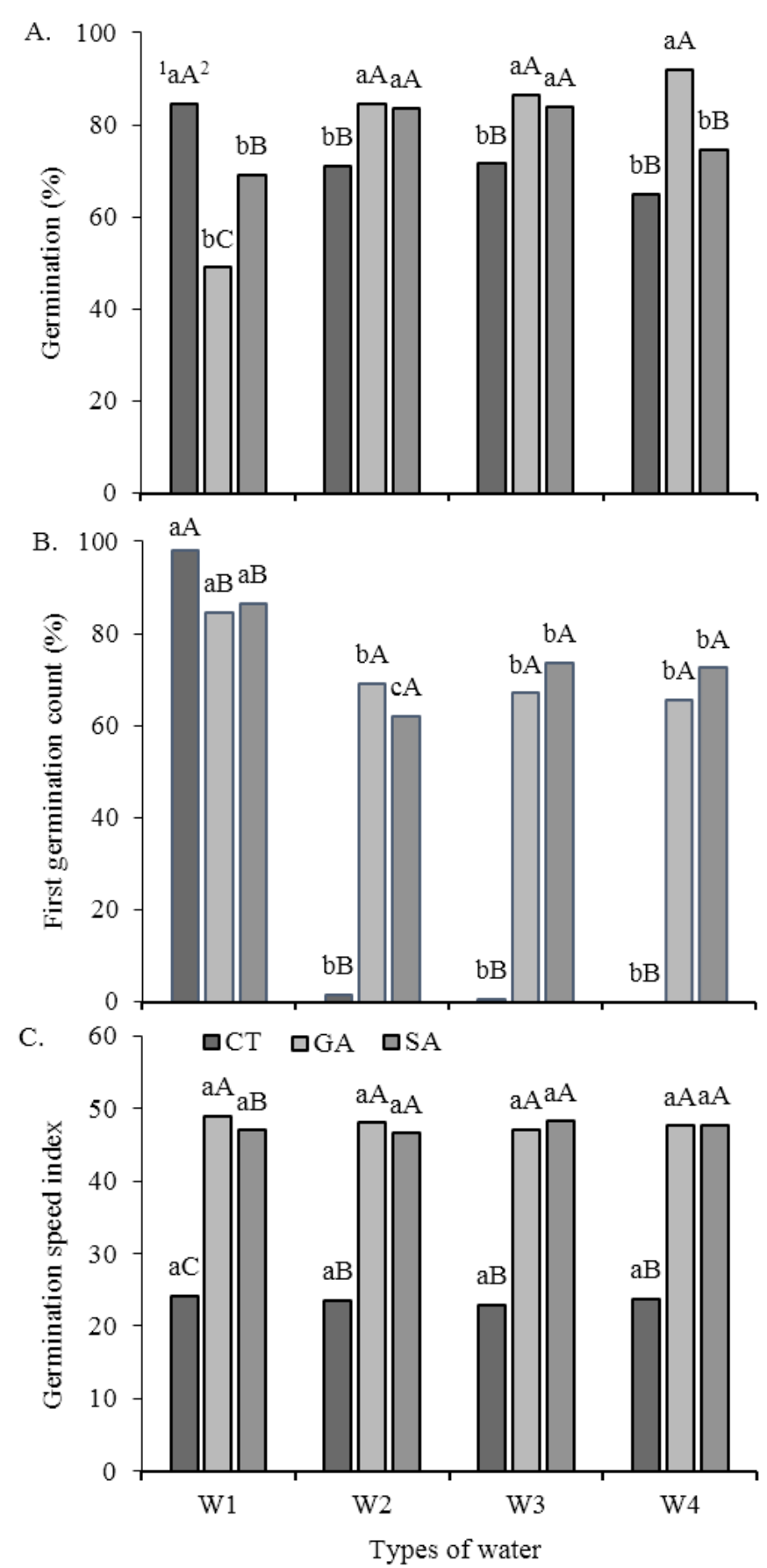

$\mathrm{W}_{1}$ - Supply water; $\mathrm{W}_{2}$ - Fish farming wastewater; $\mathrm{W}_{3}$ - Artesian well water; $\mathrm{W}_{4}$ - Mixture of fish farming wastewater + artesian well water, in 1:1 proportion $\left(\mathrm{W}_{2}+\mathrm{W}_{3}\right)$; CT - Control; GA - Gibberellic acid; SA - Salicylic acid; ${ }^{1}$ Means followed by the same lowercase letter do not differ for the types of water within the phytohormones by the Scott Knott test ( $\mathrm{p}$ $\leq 0.05) ;{ }^{2}$ Means followed by the same uppercase letter do not differ for phytohormones by Scott-Knott test $(\mathrm{p} \leq 0.05)$

Figure 1. Germination (A), first germination count (B) and germination speed index (C) of pumpkin seeds, cv. Sergipana, pretreated with phytohormones and subjected to different types of water

The gibberellic and salicylic acids also increased germination speed index in seeds of Cucurbita pepo L. (Rafique et al., 2011) and Citrullus lanatus L. (Silva et al., 2014b). The same occurred for seeds of Zea mays L., whose treatment with gibberellic acid reduced germination time (Tsegay \& Andargie, 2018). These phytohormones interact, promoting increased expression of genes involved in the synthesis and action of salicylic acid. Through the exogenous application of these regulators, their content in the seeds is increased, promoting more cell 
differentiation and elongation (Taiz et al., 2017), which is expressed in more germination. In addition, the lower osmotic potential in the substrate reduces the water requirement by the seed to perform germination (Carvalho \& Nakagawa, 2012).

Shoot length was influenced by the phytohormones under the supply water $\left(\mathrm{W}_{1}\right)$ and fish farming wastewater $\left(\mathrm{W}_{2}\right)$ (Figure 2A). Gibberellic and salicylic acids are associated with growth metabolism and plant defense, and in this case, even under conditions of salt stress, these phytohormones influence cell elongation and shoot growth (Javaid \& Tanveer, 2014). Results similar to that found in this study were obtained in Cucurbita moschata seedlings from the use of $30 \mathrm{mg} \mathrm{L}^{-1}$ salicylic acid (Rafique et al., 2011). However, Silva et al. (2015) found that fish farming wastewater favored the length of Citrullus lanatus seedlings. This was not observed in the present study for the cv. Sergipana, since the high electrical conductivity of these waters hampered the shoot length of the seedlings, due to the osmotic and toxic effects of the ions (Nóbrega et al., 2020).

Regarding root length, there were no significant effects of seed treatment with phytohormones under supply water $\left(\mathrm{W}_{1}\right)$ and artesian well water $\left(\mathrm{W}_{3}\right)$. However, under fish farming wastewater $\left(\mathrm{W}_{2}\right)$, seeds treated with gibberellin and salicylic acid resulted in greater root length $(13.5$ and $12.8 \mathrm{~cm}$, respectively). For the mixture of fish farming wastewater + artesian well water $\left(\mathrm{W}_{4}\right)$, seeds treated with salicylic acid had superior root length (Figure 2B). This behavior is related to the function of these acids, which are involved in physiological and biochemical processes, thus reducing the toxic effects imposed on plants (Rafique et al., 2011), in this case, salt stress. In addition, in Citrullus lanatus, Silva et al. (2014b) found that the use of gibberellic acid at dose of up to100 $\mu \mathrm{g} \mathrm{g}^{-1}$, under non-saline conditions, did not influence root development. However, in seedlings of Cucurbita maxima, cv. Moranga, root length was hampered, while the $\mathrm{cv}$. Jacarezinho increased its root length as the concentrations of fish farming wastewater increased, even without the use of any plant regulator (Silva et al., 2014a). As can be seen, plant hormones are very sensitive to changes in concentration, showing differences in behavior according to the species, cultivar and/or condition to which plants are subjected.

For shoot dry mass of the seedlings (Figure 2C), phytohormones did not differ statistically within the treatments with supply water $\left(\mathrm{W}_{1}\right)$, well water $\left(\mathrm{W}_{3}\right)$ and fish farming wastewater + well water $\left(\mathrm{W}_{4}\right)$. However, the application of gibberellic acid and the control led to values $19.1 \mathrm{mg}$ higher than those obtained with the salicylic acid treatment under fish farming water $\left(\mathrm{W}_{2}\right)$.

Under stress conditions, plants adjust their metabolism to overcome the toxic effects of salts. However, when gibberellic acid is applied, this effect is attenuated, allowing the plant to continue its development (Rafique et al., 2011). As gibberellins act in the breaking of reserves through enzymes in seeds, their exogenous application promotes greater cell elongation (Marcos-Filho, 2015). In the present study, there was a longer root length of the seedlings, but with lower root dry mass, because in stressful situations the seedlings grow less vigorous and concentrate their development in the root system, to overcome the effects of the saline environment, without
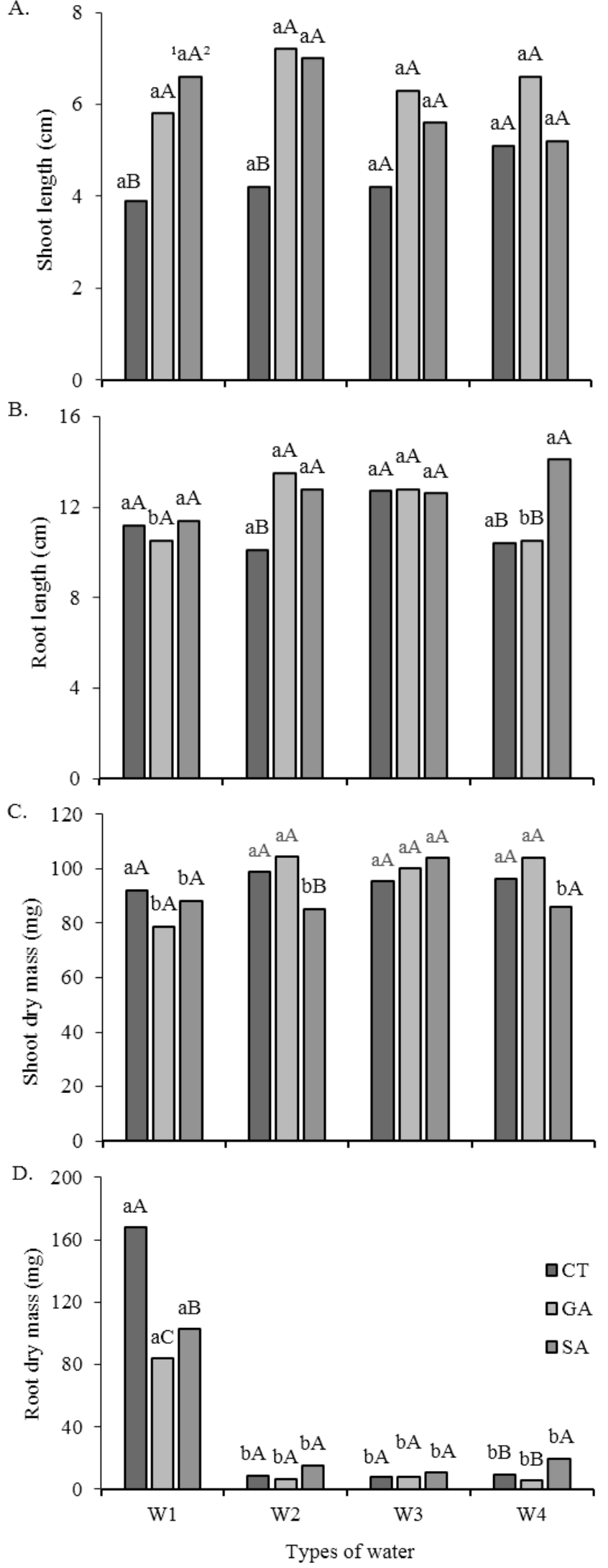

$\mathrm{W}_{1}$ - Supply water; $\mathrm{W}_{2}$ - Fish farming wastewater; $\mathrm{W}_{3}$ - Artesian well water; $\mathrm{W}_{4}$ - Mixture of fish farming wastewater + artesian well water, in 1:1 proportion $\left(\mathrm{W}_{2}+\mathrm{W}_{3}\right)$; CT - Control; GA - Gibberellic acid; SA - Salicylic acid; ${ }^{1}$ Means followed by the same lowercase letter do not differ for the types of water within the phytohormones by the Scott-Knott test ( $\mathrm{p}$ $\leq 0.05) ;{ }^{2}$ Means followed by the same uppercase letter do not differ for phytohormones by the Scott-Knott test $(\mathrm{p} \leq 0.05)$

Figure 2. Shoot length (A), root length (B), shoot dry mass (C) and root dry mass (D) of pumpkin seedlings, cv. Sergipana, grown from seeds pretreated with phytohormones and subjected to different types of water 
accumulating metabolites in sufficient proportions for a better establishment.

A similar result was observed in Cucurbita maxima

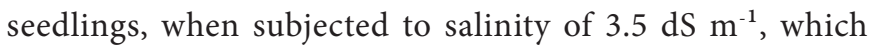
caused a negative effect on this variable (Oliveira et al., 2014). On the other hand, the same did not occur in Citrullus lanatus seedlings, under non-saline conditions, where gibberellic acid positively influenced shoot dry mass (Silva et al., 2014). For artesian well water $\left(\mathrm{W}_{3}\right)$, there was no difference between seed treatments regarding the increase of shoot dry mass. The chemical characteristics of the water, which normally contains high load of organic residues, possibly interfered with the nutrition of the seedlings (Oliveira \& Santos, 2015).

Initially, it is very likely that the seedling will maintain its physiological system focused on root growth, because in stressful environments, especially with water restriction and excess of salts, it needs to be established quickly, so it prioritizes cell elongation. Thus, while this phase of rooting occurs, the metabolism for accumulation of shoot dry mass occurs simultaneously, but now at a slower pace. This result indicates that seedlings tend to show this behavior in the initial development, which may be different in seedlings, because the metabolism will be more focused on shoot formation, possibly affecting dry mass and length (Taiz et al., 2017).

Seedlings with highest root dry mass production were obtained under supply water $\left(\mathrm{W}_{1}\right)$ with the control treatment of seeds $(167.8 \mathrm{mg})$, since plant regulators limited the investment in root under non-saline conditions. Both in treatments with plant regulators and in the control, the supply water led to seedlings with higher root dry mass (Figure 2D).

Waters with higher salt contents caused greater losses of root dry mass and were not influenced by the action of regulators, with a reduction in the values of approximately $91 \mathrm{mg}$. Therefore, under stress conditions, these acids did not act in the same way to ensure and/or maintain root growth, often characterized by thicker roots, which concentrate their development in root elongation to seek water and overcome osmotic stress. This fact explains the lower root dry mass, despite the greater root length of the seedlings under more saline waters.

Application of the regulators did not hamper root dry mass under non-saline conditions. However, in other species, such as Allium cepa L., the physiological priming of seeds with 50 $\mu \mathrm{M}$ of salicylic acid promoted an increase in root dry mass (Silva et al., 2019).

When seedlings are under stress, the products can act as attenuators, enabling the establishment of seedlings (Khan et al., 2015). This was evidenced by analyzing studies carried out with initial treatment of Medicago sativa L. seeds with gibberellic acid, which reduced the negative effect of salts on seedling growth (Younesi \& Moradi, 2014). Moreover, reuse water, such as fish farming wastewater, has high conductivity, but with elements that are not always harmful. Among the salts of these waters, there may be nutrients that help in plant development (Dantas et al., 2014).

In the evaluation of the concentration of soluble sugars (Figure 3A), there was greater accumulation in seedlings of the control treatment in the supply water $\left(\mathrm{W}_{1}\right)$ and fish farming wastewater + well water $\left(\mathrm{W}_{4}\right)$, which led to values
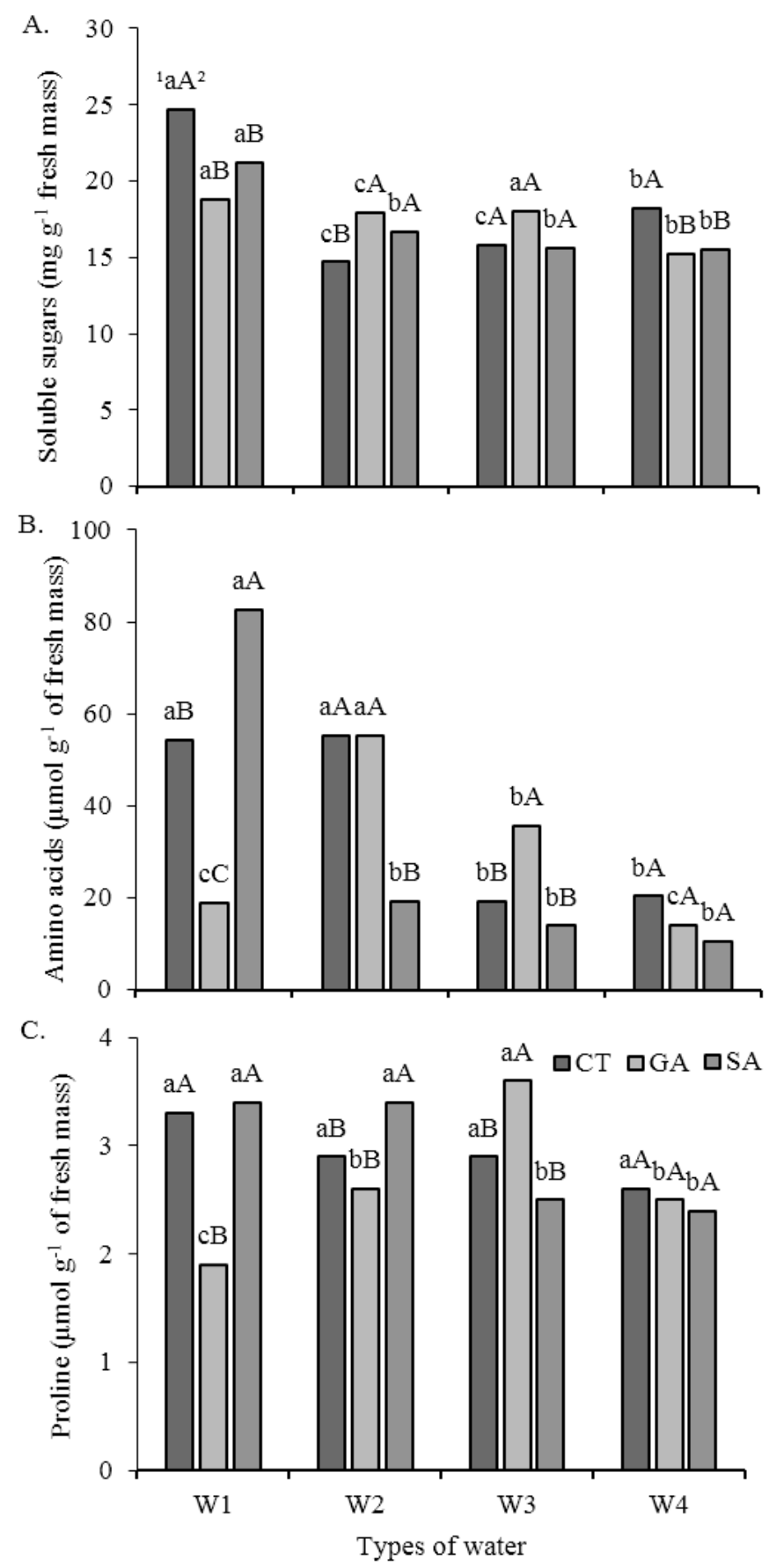

$\mathrm{W}_{1}$ - Supply water; $\mathrm{W}_{2}$ - Fish farming wastewater; $\mathrm{W}_{3}$ - Artesian well water; $\mathrm{W}_{4}$ - Mixture of fish farming wastewater + artesian well water, in 1:1 proportion $\left(\mathrm{W}_{2}+\mathrm{W}_{3}\right)$; CT - Control; GA - Gibberellic acid; SA - Salicylic acid; ${ }^{1}$ Means followed by the same lowercase letter do not differ for the types of water within the phytohormones by the Scott-Knott test ( $\mathrm{p}$ $\leq 0.05) ;{ }^{2}$ Means followed by the same uppercase letter do not differ for phytohormones by the Scott-Knott test ( $\mathrm{p} \leq 0.05)$

Figure 3. Soluble sugars (A), amino acids (B) and proline (B) in pumpkin seedlings, cv. Sergipana, grown from seeds pretreated with phytohormones and subjected to different types of water

approximately $15 \%$ higher than those obtained with the plant regulators in both waters. However, the gibberellic and salicylic acids enabled greater accumulation of total sugars in seedlings subjected to fish farming wastewater. Thus, the increase in sugar concentrations can be considered important as an adaptive response, due to its role in osmotic adjustment and consequent protection of cellular structures, occurring in stressful situations (Esteves \& Suzuki, 2008). These sugars reduce the cellular osmotic potential, allowing the cell to maintain hydration and turgor pressure, even under 
a condition of low water availability, caused by osmotic stress (Singh \& Gautam, 2013).

In the evaluation of amino acids, only salicylic acid enabled greater accumulation, which was $77 \%$ higher than the value obtained with the use of gibberellic acid under supply water $\left(\mathrm{W}_{1}\right)$ (Figure $3 \mathrm{~B}$ ). In more saline waters, such as $\mathrm{W}_{3}$, seeds treated with gibberellic acid accumulated more amino acids, showing the effect of this regulator as attenuator of the stress imposed on seedlings. Paiva et al. (2018) also verified increase in amino acid concentration in Salvia hispanica L. seedlings under salinity conditions. In Cucumis sativus L. seedlings whose seeds were osmoprimed with saline water, Matias et al. (2018) found that there was accumulation of amino acids, possibly due to osmotic adjustment.

The gibberellic acid applied to seeds subjected to artesian well water $\left(\mathrm{W}_{3}\right)$ also led to higher proline accumulation, while salicylic acid promoted the accumulation of this metabolite only under fish farming wastewater $\left(\mathrm{W}_{2}\right)$ (Figure $3 \mathrm{C}$ ). Usually, proline accumulation is linked to situations of abiotic stress, as verified in Lippia sidoides (Cham), exposed for long periods (Alvarenga et al., 2011) and in seedlings of Salvia hispanica L. (Paiva et al., 2018).

In general, the use of phytohormones in the treatment of pumpkin seeds was beneficial to germination and seedling growth, especially when low quality waters were used. Gibberellic and salicylic acids influenced the accumulation of metabolites, especially those related to osmotic adjustment.

\section{Conclusion}

Treatment of pumpkin seeds, cv. Sergipana, with gibberellic and salicylic acids improve germination kinetics under saline water conditions and attenuate the effects of water salinity during the initial growth of pumpkin seedlings.

\section{ACKNOWLeDgments}

This study was carried out with support from the Coordenação de Aperfeiçoamento de Pessoal de Nível Superior - Brazil (CAPES) - Financing Code 001.

\section{Literature Cited}

Alvarenga, I. C. A.; Queiroz, G. A.; Honório, I. C. G.; Valadares, R. V.; Martins, E. R. Prolina livre em alecrim-pimenta sob estresse hídrico antes da colheita. Revista Brasileira de Plantas Medicinais, v.13, p.539-541, 2011. https://doi.org/10.1590/S151605722011000500006

Bates, L. S.; Waldren, R. P.; Teare, I. D. Rapid determination of free proline for water-stress studies. Plant and Soil, v.39, p.205-207, 1973. https://link.springer.com/article/10.1007/BF00018060

Brasil. Ministério da Agricultura, Pecuária e do Abastecimento. Regras para análise de sementes. Brasília: MAPA, 2009. 395p.

Carvalho, N. M.; Nakagawa, J. Sementes: Ciência, tecnologia e produção. 5.ed. Jaboticabal: FUNEP, 2012. 588p.

Castro, R. S.; Azevedo, C. M. S. B.; Bezerra Neto, F. Increasing cherry tomato yield using fish effluent as irrigation water in Northeast Brazil. Scientia Horticulturae, v.110, p.44-50, 2006. https://doi. org/10.1016/j.scienta.2006.06.006
Dantas, B. F.; Ribeiro, R. C.; Matias, J. R.; Araújo, G. G. L. Germinative metabolism of Caatinga forest species in biosaline agriculture. Journal of Seed Science, v.36, p.194-203, 2014. https://doi. org/10.1590/2317-1545v32n2927

Devi, N. M.; Prasad, R. V.; Sagarika, N. A review on health benefits and nutritional composition of pumpkin seeds. International Journal of Chemical Studies, v.6, p.1154-1157, 2018.

Esteves, B. S.; Suzuki, M. S. Efeito da salinidade sobre as plantas. Oecologia Brasiliensis, v.12, p.662-679, 2008. https://dx.doi. org/10.4257/oeco.2008.1204.06

Ferreira, D. F. Sisvar: A computer statistical analysis system. Ciência e Agrotecnologia, v.35, p.1039-1042, 2011. https://dx.doi. org/10.1590/S1413-70542011000600001

Javaid, M. M.; Tanveer, A. Germination ecology of Emex spinosa and Emex australis, invasive weeds of winter crops. Weed Research, v.54, p.565-575, 2014. https://doi.org/10.1111/wre.12111

Kandil, A. A.; Sharief, A. E.; Abido, W. A. E.; Awed, A. M. Effect of gibberellic acid on germination behaviour of sugar beet cultivars under salt stress conditions of Egypt. Sugar Tech, v.16, p.211-221, 2014. https://doi.org/10.1007/s12355-013-0252-7

Khan, M. I. R.; Fatma, M.; Per, T. S.; Anjum, N. A.; Khan, N. A. Salicylic acid-induced abiotic stress tolerance and underlying mechanisms in plants. Frontiers in Plant Science, v. 6, p.1-17, 2015. https://doi.org/10.3389/fpls.2015.00462

Maguire, J. D. Speed of germination aid in selection and evaluation for seedling and vigour. Crop Science, v.2, p.176-177, 1962. http:// doi.org/10.2135/cropsci1962.0011183X000200020033x

Marcos-Filho, J. Fisiologia de sementes de plantas cultivadas. 2.ed. Londrina: ABRATES, 2015. 660p.

Matias, J. R.; Torres, S. B.; Leal, C. C. P.; Leite, M. S.; Carvalho, S. M. C. Hydropriming as inducer of salinity tolerance in sunflower seeds. Revista Brasileira de Engenharia Agrícola e Ambiental, v.22, p.255-260, 2018. http://dx.doi.org/10.1590/1807-1929/agriambi. v22n4p255-260

Nóbrega, J. S.; da Silva, T. I.; da Silva Ribeiro, J. E.; de Sousa Vieira, L.; Figueiredo, F. R. A.; de Fátima, R. T.; Dias, T. J. Emergência e crescimento inicial de melancia submetida a salinidade e doses de ácido salicílico. Desafios - Revista Interdisciplinar da Universidade Federal do Tocantins, v.7, p.162-171, 2020. http:// dx.doi.org/10.20873/ufv7-8169

Oliveira, E. G.; Santos, F. J. S. Piscicultura e os desafios de produzir em regiões com escassez de água. Ciência Animal, v.25, p.133154, 2015.

Oliveira, F. D. A.; Martins, D. C.; Oliveira, M. K. T.; Souza Neta, M. L. de; Silva, R. T. Desenvolvimento inicial de cultivares de abóboras e morangas submetidas ao estresse salino. Revista Agro@mbiente On-line, v.8, p.222-229, 2014. http://dx.doi.org/10.18227/19828470ragro.v8i2.1540

Ó, L. M. G.; Cova, A. M. W.; Gheyi, H. R.; Silva, N. D.; Azevedo Neto, A. D. Production and quality of mini watermelon under drip irrigation with brackish water. Revista Caatinga, v.33, p.766-774, 2020. http://dx.doi.org/10.1590/1983-21252020v33n320rc

Paiva, E. P.; Torres, S. B.; Alves, T. R. C.; Sá, F. V. S.; Leite, M. D. S.; Dombroski, J. L. D. Germination and biochemical components of Salvia hispanica L. seeds at different salinity levels and temperatures. Acta Scientiarum. Agronomy, v. 40, p.1-7, 2018. http://dx.doi.org/10.4025/actasciagron.v40i1.39396 
Rafique, N.; Raza, S. H.; Qasim, M.; Iqbal, N. A. E. E. M. Pre-sowing application of ascorbic acid and salicylic acid to seed of pumpkin and seedling response to salt. Pakistan Journal of Botany, v.43, p.2677-2682, 2011.

Resende, G. M.; Borges, R. M. E.; Goncalves, N. P. S. Produtividade da cultura da abóbora em diferentes densidades de plantio no Vale do São Francisco. Horticultura Brasileira, v.31, p.504-508, 2013. http://dx.doi.org/10.1590/S0102-05362013000300027

Richards, L.A. Diagnosis and improvement of saline and alkali soils. Agricultural Handbook, 60. Washington: US Department of Agriculture, 1954. 160p.

Silva, J. E. S.; Barbosa, L. G.; Silva, F. Z.; Silva, T. B.; Matias, J. R.; Ribeiro, R. C.; Dantas, B. F. Produção de mudas de moranga e abóbora irrigadas com água biossalina. Scientia Plena, v.10, n.10, p.1-7, 2014a.

Silva, J. E. S. B.; Matias, J. R.; Guirra, K. S.; Aragão, C. A.; Araujo, G. G. L.; Dantas, B. F. Development of seedlings of watermelon cv. Crimson Sweet irrigated with biosaline water. Revista Brasileira de Engenharia Agrícola e Ambiental, v.19, p.835-840, 2015. http:// dx.doi.org/10.1590/1807-1929/agriambi.v19n9p835-840

Silva, J. E. S. B.; Paiva, E. P.; Leite, M. S.; Torres, S. B.; Souza Neta, M. L.; Guirra, K. S. Salicylic acid in the physiological priming of onion seeds subjected to water and salt stresses. Revista Brasileira de Engenharia Agrícola e Ambiental, v.23, p.919924, 2019. http://dx.doi.org/10.1590/1807-1929/agriambi. v23n12p919-924
Silva, T. C. F. S.; Silva, R. C. B.; Silva, J. E. S. B.; Santos, R. S.; Aragão, C. A.; Dantas, B. F. Germinação de sementes de melancia sob diferentes métodos de tratamento com reguladores vegetais. Scientia Plena, v.10, n.3, p.1-15, 2014b.

Singh, P. K.; Gautam, S. Role of salicylic acid on physiological and biochemical mechanism of salinity stress tolerance in plants. Acta Physiologiae Plantarum, v.35, p.2345-2353, 2013. https:// doi.org/10.1007/s11738-013-1279-9

Taiz, L.; Zeiger, E.; Møller, I. M.; Murphy, A. Fisiologia e desenvolvimento vegetal. Porto Alegre: Artmed Editora, 2017. 888p.

Tsegay, B. A.; Andargie, M. Seed priming with gibberellic acid $\left(\mathrm{GA}_{3}\right)$ alleviates salinity induced inhibition of germination and seedling growth of Zea mays L., Pisum sativum var. abyssinicum A. Braun and Lathyrus sativus L. Journal of Crop Science and Biotechnology, v.21, p.261-267, 2018. https://doi.org/10.1007/s12892-018-0043-0

Yemm, E. W.; Cocking, E. C. The determination of amino-acids with ninhydrin. Analyst, v.80, p.209-213, 1955. https://doi.org/10.1039/ AN9558000209

Yemm, E. W.; Willis, A. J. The estimation of carbohydrates in plant extracts by anthrone. Biochemical Journal, v.57, p.508, 1954. https://doi.org/10.1042/bj0570508

Younesi, O.; Moradi, A. Effect of priming of seeds of Medicago sativa 'bami'with gibberellic acid on germination, seedlings growth and antioxidant enzymes activity under salinity stress. Journal of Horticultural Research, v.22, p.167-174, 2014. https://doi. org/10.2478/johr-2014-0034 